\title{
Geochemistry of the Early Cretaceous Laiyang Group in Lingke-I core, Shandong Province, Eastern China: Implications for provenance, tectonic setting and paleoenvironment
}

\author{
QING MA ${ }^{1}$, YAOQI ZHOU ${ }^{2 *}$ \\ ${ }^{1,2}$ School of Geosciences, China University of Petroleum \\ (East China), Qingdao266580, China \\ ${ }^{1}$ mqstudy@163.com \\ 2 zhouyq@upc.edu.cn (*corresponding author)
}

Early Cretaceous sedimentary rocks on Lingshan island, located at the continental margin of East Asia, have received increasing interests in recent years. The LK1 core shows the early Cretaceous Laiyang Group. This study integrated geochemistry to investigates the provenance, tectonic setting, paleocliamte and paleoredox conditions of the studied area, to elucidate the depositional history of the early Cretaceous sediments in this area and reconstruct the paleoenviroment.

The 90 sandstones and 76 mudstones were collected from the LK1 core. Most of the samples have chemical index of alternation (CIA) values less than 50 reflecting relatively weak chemical weathering and stable tectonic background in the source area. The geochemical characteristics (plots of $\mathrm{TiO}_{2}-\mathrm{Al}_{2} \mathrm{O}_{3}, \mathrm{TiO}_{2}-\mathrm{Zr}, \mathrm{F}_{2}-\mathrm{F}_{1}, \mathrm{Th} / \mathrm{Sc}-\mathrm{Zr} / \mathrm{Sc}, \mathrm{Cr} / \mathrm{Th}-\mathrm{Sc} / \mathrm{Th}$, $\mathrm{La} / \mathrm{Yb}-\sum \mathrm{REE}, \mathrm{La} / \mathrm{Th}-\mathrm{Hf}$, Eu anomaly) demonstrate that the sedimentary sources were felsic rocks. Plots of $\mathrm{Na}_{2} \mathrm{O} / \mathrm{K}_{2} \mathrm{O}-$ $\mathrm{SiO}_{2} / \mathrm{Al}_{2} \mathrm{O}_{3}$ illustrate that the type of these samples were graywacke. The bivariate diagrams $\left(\mathrm{K}_{2} \mathrm{O} / \mathrm{Na}_{2} \mathrm{O}\right.$ vs. $\mathrm{SiO}_{2}$, $\mathrm{Al}_{2} \mathrm{O}_{3} / \mathrm{SiO}_{2}$ vs. $\left(\mathrm{Fe}_{2} \mathrm{O}_{3}{ }^{\mathrm{T}}+\mathrm{MgO}\right), \mathrm{Al}_{2} \mathrm{O}_{3} /\left(\mathrm{CaO}+\mathrm{Na}_{2} \mathrm{O}\right)$ vs. $\left(\mathrm{Fe}_{2} \mathrm{O}_{3}{ }^{\mathrm{T}}+\mathrm{MgO}\right), \mathrm{DF}_{2}$ vs. $\left.\mathrm{DF}_{1}\right)$ and the ternary diagrams (La$\mathrm{Th}-\mathrm{Sc}, \mathrm{Th}-\mathrm{Sc}-\mathrm{Zr} / \mathrm{10}$ ) indicate that the source rocks were mainly originated from island arc and active continental margin. The Ce anomaly that has shown in these samples can be used to testify seawater as a source of REEs in the deposits.

Several representative geochemical data $\left(\mathrm{SiO}_{2} / \mathrm{Al}_{2} \mathrm{O}_{3}, \mathrm{C}\right.$ value, $\mathrm{Sr} / \mathrm{Cu}, \mathrm{Rb} / \mathrm{Sr})$ and the bivariate plot of $\mathrm{SiO}_{2}$ vs. $\left(\mathrm{Al}_{2} \mathrm{O}_{3}\right.$ $+\mathrm{K}_{2} \mathrm{O}+\mathrm{Na}_{2} \mathrm{O}$ ) in this core show that the Laiyang group was mainly deposited in the arid conditions. The $100 \mathrm{MgO} / \mathrm{Al}_{2} \mathrm{O}_{3}$, $\mathrm{V}$ concentration and $\mathrm{Sr} / \mathrm{Ba}$ suggests a paleosalinity transition from a brackish environment to saline environment, and then brackish environment. The $\mathrm{U} / \mathrm{Th}, \mathrm{V} /(\mathrm{V}+\mathrm{Ni})$ and $\mathrm{Ce}$ anomaly of rocks are indicators of anoxic conditions. Simultaneously, the obvious decline trends of above three geochemical indexes showing in the part of $400 \mathrm{~m}-800 \mathrm{~m}$ may be related to latest Hauterivian oceanic anoxic event. Combined above results, these geochemical data also demonstrate that the depositional environment was marine rifting basin. 